\title{
PÄÄKIRJOITUS
}

\section{Tiedelehtien muovautuva maisema}

\author{
Mikael Laakso \\ Hanken \\ mikael.laakso@hanken.fi \\ https://orcid.org/0000-0003-3951-7990
}

Asiasanat: pääkirjoitukset, tiedelehdet

Tiedelehdet ja niiden muodostama kokonaismaisema ovat ajan saatossa muovatuneet tieteellisen viestinnän tarpeista ja teknologian kehityksen vaikutuksesta. Digitalisaatio on viime vuosikymmenten aikana mahdollistanut uusien lehtien synnyn kovempaan tahtiin kuin koskaan aikaisemmin. Tässä pääkirjoituksessa peilaan lyhyesti tiedelehtien maiseman laajempaa kehitystä sekä Informaatiotutkimus-lehteä osana tätä kokonaisuutta.

Artikkeli on lisensoitu Creative Commons Nimeä-EiKaupallinen-JaaSamoin 4.o Kansainvälinen -lisenssillä 
Informaatiotutkimus-lehti täyttää tänä vuonna 40 vuotta, ikä joka on merkittävä tiedejulkaisemisen kentällä. Ulrichsweb Global Serials Directoryn mukaan maailmassa on tällä hetkellä 47257 aktiivista vertaisarvioitua tiedelehteä (maaliskuu 2021). Palvelussa on 12294 lehteä joiden aloitusvuodeksi on merkattu 1981 tai sitä ennen, eli Informaatiotutkimus on miltei mukana vanhimman neljänneksen joukossa (vain 26\% kaikista lehdistä ovat samanikäisiä tai vanhempia). Nykyaikoina uusia lehtiä syntyy kuin sieniä sateella. Tällöin pitkä historia ja perinteet auttavat luomaan vakaan pohjan ja uskottavuutta, niin lukijoiden kuin kirjoittajien silmissä.

Mutta ikä ei ole ainoa merkittävä ja poikkeuksellinen asia Informaatiotutkimus-lehden osalta. Jos tarkastellaan lehtien eri ominaisuuksia kokonaiskuvassa, merkittävää ja poikkeuksellista on myös avoin julkaiseminen. Ulrichsweb palvelun tietojen mukaan 43346 kaikista lehdistä julkaisee sisältöään verkkoon jossain muodossa, useimmat vielä maksumuurin taakse. The Directory of Open Access Journals palveluun on rekisteröity yhteensä 15 996 aktiivista lehteä, joten näiden tietojen perusteella 34\% kaikista lehdistä julkaisee tällä hetkellä kaiken sisällön avoimesti verkkoon ilman viivettä. Informaatiotutkimus kuuluu tähän edistykselliseen joukkoon lehtiä. Lehti ottaa avoimella julkaisemisella ja maksuttomuudella kirjoittajille kaiken hyödyn irti kustannustehokkaasta digitaalisesta julkaisemisesta, näin välttäen kirjoittajamaksujen luomaa kynnystä osallistumiseen.

Tiedelehtien maisemaan vaikuttaa tiedeviestinnän muuttuvien tarpeiden ja teknologian kehityksen lisäksi tiedepolitiikka ja kaupalliset voimat, ja väittäisin että näiden vaikutus on merkittävästi voimistunut viime vuosikymmenen aikana.

Kansainväliset tiedelehtien kustantajat ovat vuodesta toiseen kasvaneet entistä suuremmiksi, niin julkaisuvolyymien kuin myös kirjastojen budjettien menojen osuuksien puolesta. Tämä luo vastaavasti kirjastoille vaikeuksia rahoittaa julkaisutoimintaa isojen sopimusten ulkopuolelta, niin kuin esimerkiksi kotimaisia tiedelehtiä, olemassa olevin budjettivaroin ja rahoitusmekanismein. Kansainvälisten kustantajien korkeana prioriteettina on viime vuosina ollut markkinaosuuksien kasvattaminen varsinkin avoimen julkaisemisen toimintamallin lehdissä, kuitenkin pitämällä suurimman osan vanhoista ja vakiintuneista lehdistä tilauspohjaisina. Tästä viimeisimpänä esimerkkinä on yli 200 lehden siirtyminen yksityisomisteiselta Hindawilta Wileylle aikaisemmin tänä vuonna osana isoa yrityskauppaa (Wiley 2021). Raha ratkaisee monesti ja vastaavat siirrot pienemmissä määrin ovat arkipäivää, kun lehtiä siirtyy kustantajien kesken ikään kuin kauppatavara tai arvopaperit (Journaltransfer ISSN 2021). Tästä syystä näen tärkeänä, että lehdet pysyvät tiedeyhteisön omistuksessa ja kontrollissa vaikka julkaisemisen toimintoja 
ulkoistetaan ja kilpailutetaan. Tällöin muutoksia ei tehdä pelkästään taloudellisten strategioiden ja kvartaalilaskelmien perusteella vaan tiedeyhteisön parhaaksi. Tässäkin asiassa Informaatiotutkimus ja suurin osa kotimaisista tiedelehdistä näyttää hyvää esimerkkiä.

Tiedepolitiikan esittäminen erillisenä voimana on ehkä jopa asioiden yksinkertaistamista liiaksi, sillä siitä on muodostunut tiedelehtien maailmassa asia, joka on läheisesti kytketty taloudellisiin markkinamekanismeihin. Tiedelehtien kontekstissa tiedepolitiikka on mukana reguloimassa sekä kysyntää että tarjontaa. Esimerkiksi isojen kansainvälisten tutkimusrahoittajien yhteenliittymä cOAlition S ohjaa rahoitettuja tutkijoita julkaisemaan vain heidän ehtojen kanssa yhteensopivissa avoimissa lehdissä ns. Plan S aloitteen kautta (tässä yhteenliittymässä mukana myös Suomen Akatemia). Aloitteen alkuperäisen vetäjän mukaan lyhennettä "S" ei ole tarkasti määritelty mutta ehdotti yhtenä mahdollisuutena sanaa "shock" (Else 2018). Plan S on kyllä ollut jonkinasteinen sokki tiedejulkaisemisessa, sillä cOAlition S perää suurempaa läpinäkyvyyttä kustantajien kustannuksiin, yhtenä keinona hillitä hintojen nousua. Plan S yrittää siis vaikuttaa sekä kysyntään (missä rahoitetut tutkijat saavat julkaista) että tarjontaan (miten tiedelehtien maisema muovautuu vaatimusten kautta, millaiseksi hinnoittelu muodostuu). Konkreettisena kotimaisena esimerkkinä tiedepolitiikan vaikutuksesta tiedejulkaisemiseen on opetus- ja kulttuuriministeriön käyttämä rahoitusmalli, joka kannustaa ja ohjaa tutkimuksen julkaisukäyttäytymistä yhdistettynä Julkaisufoorumin tasoluokitusten kanssa. Sekä kirjastot että kustantajat voivat käyttää hyödyksi tällaisia luokituksia lehtipakettien sopimusneuvotteluissa isojen kustantajien kanssa, kun eri aineistopakettien relevanssista ja hinnoittelusta vedetään köyttä säännöllisin väliajoin.

Vaikka tiedejulkaisemisessa arvostetaan pitkää historiaa ja perinteitä niin yksittäiset lehdet ovat myös muovautuvia läpi niiden elinkaarien. Esimerkiksi Informaatiotutkimuksen nimi oli vuoteen 1995 asti Kirjastotiede ja informatiikka ja ilmestyi aluksi ainoastaan paperisena. Olen oman tutkimuksen kautta käsin selannut läpi kymmenien tuhansien eri lehtien verkkosivuja ja nähnyt miten kansainvälistyminen, yhdistymiset lehtien kesken sekä avoin julkaiseminen monesti muovaa lehtien profiileja pitkällä aikavälillä. Tässä yhteydessä on tärkeää, että lehden taustalla mahdollisesti vaikuttava tiedeyhteisö, yleensä seura niin kuin ITY ry Informaatiotutkimuksen tapauksessa, ohjaa ja tekee päätökset harkitusti omien tarpeidensa mukaisesti. Maailmassa on jo paljon geneerisiä kansainvälisiä tiedelehtiä, joten omista vahvuuksista kannattaa pitää kiinni, jotta lehti palvelisi omaa tieteenalaa ja kohdeyleisöä parhaimmalla mahdollisella tavalla. 
Vaikka lehtiä on nyt enemmän kuin koskaan, ja artikkeleita julkaistaan myös yhä kasvavissa määrin, ei kuitenkaan ole epätavallista että osa tiedelehdistä lopettaa toimintansa. Tästä aiheesta tiedämme hyvin vähän ja siinä olisikin runsaasti tilaa tutkimukselle niin kotimaisella kentällä kuin myös kansainvälisesti - milloin, miksi ja miten erilaiset tiedelehdet lopettavat aktiivisuutensa? Lehden tekeminen ja ylläpitäminen niin teknisesti, resurssoinnin puolesta ja sosiaalisesti on monen tekijän summa, jossa myös aikasemmin mainitut erilaiset toimintaympäristöä muovaavat voimat vaikuttavat, joten erilaisia tarinoita olisi varmasti paljon löydettävänä.

Tämän kirjoituksen kautta halusin korostaa lehtien muodostaman maiseman dynaamisuutta ja miten erilaiset voimat vaikuttavat yksittäisiin lehtiin ja kokonaisuuteen. Olen ylpeä siitä, että saan olla mukana tekemässä lehteä, joka on säilyttänyt relevanssinsa ja asemansa läpi vuosikymmenten, hyvin monen ihmisen pitkäjänteisen työn tuloksena, muovautuen harkitusti ympäristön muuttuessa. Jännityksellä odotan mitä tulevaisuus tuo tullessaan - vakaalta pohjalta on hyvä katsella eteenpäin!

Mikael Laakso

Espoossa 8. maaliskuuta 2021

\section{Lähteet}

Else, H. (2018). Radical open-access plan could spell end to journal subscriptions. Nature, 561(7721), 17-18. https://doi.org/10.1038/d41586-018-06178-7

Journaltransfer ISSN (2021). https://journaltransfer.issn.org/.

Wiley (2021). Wiley Announces the Acquisition of Hindawi. https://newsroom.wiley.com/pressreleases/press-release-details/2021/Wiley-Announces-the-Acquisition-of-Hindawi/ default.aspx. 5 tammikuuta 2021 